\title{
EFEKTIVITAS PELAKSANAAN PROGRAM RASKIN di DESA MANYAREJO, KECAMATAN PLUPUH, KABUPATEN SRAGEN
}

\author{
Idola Suci Utami \\ Program Studi Ilmu Administrasi Negara, Fakultas Ilmu Sosial dan Ilmu Politik, Universitas \\ Surakarta
}

\begin{abstract}
This study aims to determine the effectiveness and factors that affect the effectiveness of Raskin Rice Program Implementation in Manyarejo Village, Plupuh Sub-District, Sragen Regency.

Theories used are the theories of effectiveness, the factors of the organization that affect the effectiveness (HR, employee performance, coordination) and key success factors (transparency, community participation, supervision). This research method is descriptive qualitative research. The data used are primary data and secondary data. Data collection is done by observation method, interview and library either in the form of books, regulation and other documents. The data analysis used is qualitative data analysis with interactive method. Research location in Manyarejo Village, Plupuh District, Sragen Regency.

The results showed that the implementation of Raskin Rice Program in Manyarejo Village has been running effectively and on target with the concept of 6T that is, the right target, the right amount, the right quality, the right administration, the right time and the right price. There are only a few constraints on the Raskin distribution because the road aspect to the village of Manyarejo is somewhat damaged. It is recommended that this program be continuously implemented continuously by continuously improving its distribution management so that it can reach all RTM in the distribution point (village).
\end{abstract}

Keywords: Effectiveness, Raskin Program Implementation.

\begin{abstract}
ABSTRAK
Penelitian ini bertujuan untuk mengetahui Efektivitas dan faktor-faktor yang mempengaruhi Efektivitas pada Pelaksanaan Program Beras Raskin di Desa Manyarejo, Kecamatan Plupuh, Kabupaten Sragen.

Teori yang dipergunakan adalah teori tentang Efektivitas, faktor-faktor dari organisasi yang mempengaruhi efektivitas (SDM, kinerja pegawai, koordinasi) dan faktor kunci keberhasilan (transparansi, partisipasi masyarakat, pengawasan). Metode penelitian ini adalah penelitian deskriptif kualitatif. Data yang digunakan adalah data primer dan data sekunder. Pengumpulan data dilakukan dengan metode observasi, wawancara dan kepustakaan baik berupa buku-buku, peraturan perundangan serta dokumen lainnya. Anlisis data yang dipergunakan adalah analisis data kualitatif dengan metode interaktif. Lokasi penelitian di Desa Manyarejo, Kecamatan plupuh, Kabupaten Sragen.

Hasil penelitian menunjukkan bahwa pelaksanaan Program Beras Raskin di Desa Manyarejo sudah berjalan efektif dan tepat sasaran yang berdsasrkan konsep $6 \mathrm{~T}$ yaitu, Tepat sasaran, Tepat jumlah, Tepat kualitas, Tepat administrasi, Tepat waktu dan Tepat harga. Hanya ada sedikit kendala pada distribusi Raskin karena aspek jalan menuju desa Manyarejo agak rusak. Disarankan agar program ini terus dilaksanakan secara kontinu/berkelanjutan dengan terus-menerus memperbaiki
\end{abstract}


manajemen pendistribusiannya sehingga dapat menjangkau seluruh RTM yang ada dititik distribusi (desa).

Kata Kunci : Efektivitas, Pelaksanaan Program Raskin.

\section{PENDAHULUAN}

Sejak awal kemerdekaan bangsa Indonesia, pemerintah telah mempunyai perhatian yang sangat besar terhadap terciptanya masyarakat adil dan makmur sebagaimana diamanatkan dalam alinea ke empat Undang-Undang Dasar 1945. Hal ini tercermin dari berbagai program pembangunan yang dilaksanakan selama ini, senantiasa diarahkan dan ditujukan untuk memberikan perhatian besar terhadap upaya penanggulangan kemiskinann, karena pada dasarnya pembangunan yang dilakukan bertujuan untuk meningkatkan kesejahteraan masyarakat. Meskipun demikian, masalah kemiskinan sampai saat ini terusmenerus menjadi perhatian pemerintah, terutama penanggulangan kemiskinan masyarakat pedesaan yang merupakan mayoritas penduduk Indonesia. Walaupun demikian, kemiskinan merupakan salah satu permasalahan bangsa yang belum terselesaikan hingga saat ini. Berbagai kebijakan pemerintah telah diimplementasikan, namun hanya terkesan trial and error.

Realitas ini menunjukkan bahwa kebijakan atau program penanggulangan kemiskinan masyarakat selama ini belum menyentuh esensi kehidupan masyarakat miskin itu sendiri sebagai manusia yang memiliki hak-hak dasar. Hal ini ditegaskan dalam Rencana Kerja Pemerintah (RKP) tahun 2007 bahwa Indonesia masih menghadapi masalah kemiskinan yang antara lain ditandai oleh jumlah penduduk yang hidup dibawah garis kemiskinan dan tingginya kerentanan masyarakat untuk jatuh kebawah garis kemiskinan (Anonimous, 2007).

Raskin merupakan program pemerintah untuk membantu masyarakat miskin yang rawan pangan, agar mereka mendapatkan beras untuk kebutuhan rumah tangganya. Program Raskin termasuk bagian dari program penanggulangan kemiskinan yang terdapat pada Kluster I, yaitu tentang kegiatan perlindungan sosial berbasis keluarga dalam pemenuhan kebutuhan pangan pokok bagi masyarakat kurang mampu sudah berjalan secara rutin sejak tahun 1998. Instruksi presiden Nomor 8 tahun 2008 tentang kebijakan perberasan menginstruksikan Menteri dan Kepala Lembaga Pemerintah Non Departemen tertentu, serta Gubernur dan Bupati/Walikota seluruh Indonesia untuk melakukan upaya peningkatan pendapatan petani, ketahanan pangan, pengembangan ekonomi pedesaan serta stabilitas ekonomi nasional. Program raskin merupakan subsidi pangan sebagai bentuk upaya dari pemerintah untuk meningkatkan ketahanan pangan dan memberikan perlindungan keluarga miskin melalui pendistribusian beras yang 
diharapkan mampu menjangkau keluarga miskin, masing- masing keluarga akan menerima minimal 15 kg/ KK / bulan dengan harga Rp. 1.600 / kg di titik distribusi.

Dalam rangka pemenuhan hak dan kebutuhan pangan bagi masyarakat miskin, maka pemerintah melanjutkan program RASKIN sebagai salah satu program proteksi sosial, yang bertujuan untuk memenuhi sebagian kebutuhan pangan (beras) sehingga diharapkan dapat mengurangi beban pengeluaran keluarga miskin. RASKIN merupakan program perlindungan sosial, sekaligus sebagai pendukung program lainnya, seperti perbaikan gizi, peningkatan kesehatan, pendidikan dan peningkatan produktivitas keluarga miskin.

Untuk meningkatkan efektivitas pengelolaan program RASKIN, diperlukan adanya sinkronisasi dan koordinasi antar seluruh instansi yang terkait, mulai dari ditingkat Pusat sampai ketingkat Daerah (provinsi, kabupaten dan kota), tingkat kecamatan dan desa/kelurahan; mulai dari perencanaan sampai implementasinya, dengan melibatkan berbagai unsur masyarakat, maupun pihak lain yang terkait. Untuk menjamin efektivitas pengelolaan program Raskin, maka pemerintah menunjuk Perum Badan Urusan Logistik (Bulog) sebagai Lembaga atau badan yang bertanggung jawab untuk mendistribusikan (menyalurkan) Raskin tersebut.

Menurut Sudiarso (2012), Program Raskin adalah salah satu usaha pemerintah untuk memberikan jaminan sosial masyarakat yang tidak mampu memenuhi kebutuhan pangan. Kemenko Kesra (2013) menjelaskan bahwa keberhasilan program ini berdasarkan pada pencapaian indikator $6 \mathrm{~T}$ yakni tepat sasaran, jumlah, harga, waktu, adminstrasi, dan kualitas. Namun dalam pelaksanaannya, program ini juga tidak luput dari penyimpangan, diantaranya tidak tepat sasaran, harga, jumlah, maupun kualitas beras yang diterima.

Selama ini pelaksanaan Raskin tidak lepas dari berbagai permasalahan dan hambatan. Sebagai contoh yang dikemukakan oleh masyarakat Kecamatan Karangmalang, Kecamatan Plupuh dan kecamatan yang lain di Kabupaten Sragen antara lain beras yang diterimakan berbau apek dan berwarna kuning, volume atau jumlah yang diterimakan tidak sesuai dengan ketentuan yang sebenarnya, ketepatan distribusi dan waktu juga sering tidak sesuai jadwal dikarenakan sarana transportasi yang belum mendukung.

Hasil pengamatan awal tersebut mengindikasikan bahwa pengelolaan program Beras untuk rumah tangga miskin (Raskin) belum seluruhnya efektif, terutama dilihat dari aspek jumlah kelompok sasaran, folume beras dan harga, sehingga dapat dipastikan belum optimal memberikan kontribusi yang berati bagi peningkatan kesejahteraan hidup keluarga miskin, khususnya di desa Desa Manyarejo, Kecamatan Plupuh, Kabupaten Sragen. Temuan awal ini perlu diuji 
kebenarannya secara ilmiah melalui penelitian dalam rangka penyusunan Skripsi dengan judul : Efektivitas Pelaksanaan program Raskin di Desa Manyarejo, Kecamatan Plupuh, Kabupaten Sragen.

\section{RUMUSAN MASALAH}

Berdasarkan identifikasi masalah tersebut diatas, maka dapat dirumuskan permasalahan dalam penelitian ini, sebagai berikut : 1). Bagaimana efektivitas pelaksanaan program RASKIN di Desa Manyarejo Kecamatan Plupuh Kabupaten Sragen? 2). Faktor-faktor apa saja yang mempengaruhi efektivitas pelaksanaan program RASKIN di Desa Manyarejo Kecamatan Plupuh Kabupaten Sragen?

\section{Kerangka pemikiran}

Dewasa ini, kenyataan menunjukkan bahwa pemerintah Indonesia dihadapkan pada permasalahan kemiskinan yang cukup besar jumlahnya, dengan demikian maka upaya-upaya pemerataan pendapatan masyarakat perlu dilakukan secara terus menerus melalui berbagai bidang kehidupan masyarakat, agar mereka yang tergolong "miskin" ini setidaknya memiliki kemampuan guna memenuhi kebutuhan pokok mereka. Kebutuhan pokok yang dimaksud sebagai kebutuhan dasar (basic human needs), yakni kebutuhan yang sangat penting guna kelangsungan hidup manusia, baik yang menyangkut kebutuhan konsumsi individu (makan, perumahan, pakaian), maupun keperluan pelayanan sosial tertentu (air minum, sanitasi, transportasi, kesehatan dan pendidikan). Dalam kaitan ini, Radwan dan Alfthan (1978) mengemukakan bahwa tanpa mengurangi konsep basic needs, keperluan minimum dari seorang individu atau rumah tangga berupa: makanan, pakaian, perumahan, kesehatan, pendidikan, air dan sanitasi, transportasi dan partisipasi. Oleh karena itu dituntut adanya perubahan besar dalam pembangunan dengan berbagai sistem pendekatan yang jitu terhadap upaya peningkatan pendapatan masyarakat, penghapusan kemiskinan, dan kekurangan lapangan pekerjaan, maka upaya pendekatan basic human needs dari ILO pada dasarnya juga mencerminkan perubahan arah pembangunan ini. Dalam kaitan ini, program RASKIN merupakan salah satu kebijakan pemenuhan kebutuhan pokok rakyat, yakni kebutuhan akan pangan, khususnya beras yang cukup dengan kelompok sasaran adalah rumah tangga miskin (RTM).

Salah satu upaya yang diambil oleh pemerintah adalah dengan menerbitkan kebijakan yang tertuang dalam Inpres no 5 tahun 2015 tentang kebijakan pengadaan gabah atau beras dan penyaluran beras oleh pemerintah untuk masyarakat miskin. Program raskin ini merupakan wujud 
nyata komitmen pemerintah dalam pemenuhan kebutuhan pangan bagi masyarakat miskin melalui penyediaan beras yang bersubsidi yang bertujuan untuk mengurangi beban pengeluaran keluarga miskin dan untuk meningkatkan akses masyarakat miskin dalam pemenuhan kebutuhan pangan pokoknya sebagai salah satu hak dasar masyarakat. Dalam pelaksanaan bserta penyaluran raskin didasarkan pada suatu panduan berupa pedoman umum (Pedum) raskin tahun 2015 yang didalamnya berisi Juklak (petunjuk pelaksanaan) beserta Juklis ( petunjuk teknis) program raskin.

Dalam pelaksanaan program raskin diperlukan SDM yang handal, berpengalaman dan berpendidikan, karena SDM sangat berpengaruh terhadap efektivitas pelaksanaan program raskin, dari pendataan RTS-PM (rumah tangga sasaran penerima manfaat), sampai pada penyaluran raskin Dari TD (titik distribusi) ke TB (titik Bagi) dapat berjalan lancar dan efektif. Ada beberapa faktor kunci sebagai pendukung keberhasilan antara lain :

1. Transparansi

Prinsip transparansi dengan memberikan sosialisasi kepada warga penerima program raskin terkait arus informasi, berita, penjelasan mekanisme, prosedur, data, fakta kepada stake holder yang membutuhkan informasi secara jelas dan akurat. Masyarakat memperoleh informasi yang benar, jujur, dan tidak diskriminatif tentang pelaksanaan program raskin mulai dari pendataan RTS-PM sampai dengan penyaluran raskin di TB (titik bagi)

2. Partisipasi Masyarakat

Masyarakat dapat memberikan respon positif dalam antrian mendukung atau memberikan masukan terhadap program atau kebijakan yang diambil oleh pemerintah, namun juga dapat menolak kebijakan.

3. Pengawasan

Pengawasan mencakup upaya memeriksa apakah semua terjadi sesuai dengan rencana yang ditetapkan, perintah yang dikeluarkan, dan prinsip yang di anut, juga dimaksudkan untuk mengetahui kelemahan dan kesalahan agar dapat dihindari kejadiannya dikemudian hari. 


\section{TINJAUAN PUSTAKA}

\subsection{Penelitian terdahulu}

Mariyam Musawa dalam tesisnya yang berjudul Studi implementasi kebijakan beras untuk rumah tangga miskin (Raskin) di kelurahan Gajah Mungkur Kecamatan Gajah Mungkur Kota Semarang tahun 2009; adanya kesalahan sasaran penerima raskin meskipun dalam tingkat yang relatif rendah.

Ayu Wahyuni dalam skripsinya yang berjudul Impementasi kebijakan Raskin (beras untuk keluarga miskin) studi kasus desa Toapaya Selatan Kecamatan Toapaya Kabupaten Bintan tahun 2012; implementasi kebijakan Raskin di desa Toapaya Selatan belum terlaksana dengan efektif dan maksimal mengingat masih adanya kendala dalam tahap pendistribusian dan adanya pengaruh dari luar.

Aswardi dalam skripsinya yang berjudul Implementasi Raskin di Kecamatan Tanete Riantang Kabupaten Bone tahun 2014; implementasi Raskin di Kecamatan Tanete Riantang Kabupaten Bone belum berjalan dengan baik. Adapun permasalahan yang timbul dala implementasi raskin adalah penempatan daftar nama-nama RTS-PM yang tidak sesuai, kurangnya koodinasi pendistribusian raskin, dan kurangnya pengawasan terhadap penyaluran Raskin dari pihak yang berwenang.

\subsection{Kebijakan Publik}

Arti kebjakan publik yang disimpulkan dari Thomas Dye (2003:1) dan Anderson (2003:1) adalah langkah yang diambil pemerintah sebagai tindakan dalam mengatasi masalah yang dituangkan dalam bentuk suatu program guna kesejahteraan masyarakat. Dalam hal ini adalah penetapan progran raskin sebagai solusi untuk mengatasi masalah kerawanan pangan. Simon (2006:61) membagi klasifikasi kebijakan ,menjadi tiga (3) macam policy, yaitu Legistaive policy, managemen policy, dan working policy.

\subsection{Inpres no 5 tahun 2015}

Inpres no 5 tahun 2015 tentang kebijakan pengadaan gabah/beras oleh pemerintah untuk masyarakat miskin, terdapat pada butir kelima, yaitu menetapkan pengadaan dan penyaluran beras bersubsidi bagi kelompok masyarakat berpendapatan rendah; menetapkan kebijakan pengadaan dan penyaluran cadangan beras pemerintah untuk menjaga stabilitas harga beras, menanggulangi keadaan darurat, bencana dan rawan pangan, bantuan dan atau kerjasama internasional serta keperluan 
lain yang ditetapkan pemerintah dan; pelaksanaan kebijakan pengadaan dan penyaluran beras sebagaimana dimaksud pada angka 1 dan angka 2 dilakukan oleh BULOG.

\subsection{Program Beras Miskin}

Raskin merupakan program pemerintah untuk membantu masyarakat miskin yang rawan pangan, agar mereka mendapatkan beras untuk kebutuhan rumah tangganya. Program Raskin termasuk bagian dari program penanggulangan kemiskinan yang terdapat pada Kluster I, yaitu tentang kegiatan perlindungan sosial berbasis keluarga dalam pemenuhan kebutuhan pangan pokok bagi masyarakat kurang mampu. Program raskin merupakan subsidi pangan sebagai bentuk upaya dari pemerintah untuk meningkatkan ketahanan pangan dan memberikan perlindungan keluarga miskin melalui pendistribusian beras yang diharapkan mampu menjangkau keluarga miskin, masing- masing keluarga akan menerima minimal $15 \mathrm{~kg} /$ KK / bulan dengan harga Rp. 1.600 / kg di titik distribusi.

\subsection{Sumber Daya Manusia}

Sumber daya manusia di sektor publik adalah salah satu unsur yang paling vital didalam instansi pemerintahan, karena sumber daya manusia akan mempengaruhi efisiensi dan efektivitas pelaksanaan tugas di pemerintahan sebagai aparatur pemerintah. Dari beberapa ahli antara lain, Nawawi (2000:23) Manajemen Sumber Daya Manusia Konsep Teori dan Pengembangan dalam Konteks organisasi Publik; Wather dan Davis (1996:116) Manajemen Personalia dan Sumber Daya Manusia; Sony Sumarsono (2000:55) Ekonomi Manajemen Sumber Daya Manusia dan Ketenagakerjaan; Veithzal Rifai (2003:98) Manajemen Sumber daya Manusia untuk Perusahaan, bisa diambil kesimpulan bahwa Sumber Daya Manusia (SDM) adalah kemampuan yang dimiliki oleh pelaksana distribusi Raskin dalam menyelesaikan tugas sesuai dengan bidang dan kemampuan yang dimiliki. Profesionalisme SDM dalam melaksanakan pelayanan publik yang berorientasi pada kepentingan masyarakat adalah faktor utama dalam penyelenggaraan pelayanan publik yang berkualitas secara dinamis, tanggap, cepat, serta tepat sasaran.

\subsection{Efektivitas}

Efektivitas adalah hubungan antara output dan tujuan. Dalam artian efektivitas merupakan ukuran seberapa jauh tingkat output, kebijakan dan prosedur dari organisasi mencapai tujuan yang ditetapkan. Disebut efektif apabila tercapai tujuan ataupun sasaran seperti yang telah ditentukan. Hal ini sesuai dengan pendapat H. Emerson yang dikutip 
Handayaningrat (1994:16) efektivitas adalah pengukuran dalam arti tercapainya tujuan yang telah ditentukan sebelumnya.

Menurut Gibson et.al (2002:23) efektivitas adalah pencapaian sasaran yang telah disepakati bersama; Steers (1985:46) efektivitas adalah sejauh mana organisasi melaksanakan seluruh tugas pokoknya atau mencapai sasaran. Dari pengertian tersebut di atas dapat disimpulkan bahwa efektivitas merupakan suatu tingkat keberhasilan dari pelaksanaan suatu kegiatan organisasi sesuai dengan tugas pokoknya untuk mencapai sasaran dan tujuan yang telah ditetapkan. Dari sudut pandang bidang perilaku keorganisasian maka dapat diidentifikasikan tiga tingkatan analisis yaitu: (1) individu, (2) kelompok, dan (3) organisasi. Ketiga tingkatan analisis tersebut sejalan dengan ketiga tingkatan tanggung jawab manajerial yaitu bahwa para manajer bertanggung jawab atas efektivitas individu, kelompok dan organisasi.

Pencapaian hasil (efektivitas) yang dilakukan oleh suatu organisasi menurut Jones (1994) terdiri dari tiga tahap, yakni masukan (input), proses (conversion), dan keluaran (output) atau hasil. Input meliputi semua sumber daya yang dimiliki, informasi dan pengetahuan, bahanbahan mentah serta modal. Dalam tahap input, tingkat efisiensi sumber daya yang dimiliki sangat menentukan kemampuan yang dimiliki. Tahap proses (conversion) ditentukan oleh kemampuan organisasi untuk memanfaatkan sumber daya yang dimiliki, manajemen dan penggunaan teknologi agar dapat menghasilkan nilai. Dalam tahap ini, tingkat keahlian SDM dan daya tanggap organisasi terhadap perubahan lingkungan sangat menentukan tingkat produktifitasnya. Sedangkan dalam tahap keluaran (output), pelayanan yang diberikan merupakan hasil dari penggunaan teknologi dan keahlian SDM. Organisasi yang dapat memanfaatkan sumber daya yang dimilikinya secara efisien dapat meningkatkan kemampuannya untuk meningkatkan pelayanan dengan memuaskan kebutuhan pelanggan atau pengguna. Adapun pengukuran tehadap konsep efektivitas menurut Campbell (1989:121) adalah Keberhasilan program; keberhasilan sasaran; kepuasan terhadap program; efisiensi; pencapaian tujuan.

Salah satu faktor yang dapat mendorong peningkatan efektivitas pengelolaan program Raskin, selain penerapan fungsi-fungsi manajemen secara benar dan konsisten, juga harus mempertimbangkan beberapa nilai dasar yang dikenal dengan istilah "prinsip-prinsip pengelolaan". Adapun Prinsip pengelolaan program Raskin adalah suatu nilai-nilai dasar yang selalu menjadi landasan atau acuan dalam setiap pengambilan keputusan 
maupun tindakan yang akan diambil dalam pelaksanaan rangkaian kegiatan RASKIN. Nilai-nilai dasar tersebut diyakini mampu mendorong terwujudnya tujuan RASKIN, yaitu :

Keberpihakan kepada Rumah Tangga Miskin (RTM), yang maknanya mendorong RTM untuk ikut berperan aktif dalam perencanaan, pelaksanaan, pengendalian dan pelestarian seluruh kegiatan RASKIN baik di desa dan kecamatan, termasuk menerima manfaat atau menikmati hasilnya.

Transparansi, yang maknanya membuka akses informasi kepada lintas pelaku RASKIN terutama masyarakat penerima RASKIN, yang harus tahu, memahami dan mengerti adanya kegiatan RASKIN serta memiliki kebebasan dalam melakukan pengendalian secara mandiri.

Partisipasi, yang maknanya mendorong masyarakat berperan secara aktif dalam setiap tahapan RASKIN, mulai dari tahap sosialisasi, perencanaan, pelaksanaan, dan pengendalian.

Pengawasan, yang maknamya tindakan pemantauan atau pemeriksaan kegiatan organisasi untuk menjamin pencapaian tujuan sesuai dengan rencana yang ditetapkan sebelumnya dan melakukan tindakan korektif yang diperlukan untuk memperbaiki kesalahan yang ada sebelumnya.

Akuntabilitas, yang maknanya mengingatkan bahwa setiap pengelolaan kegiatan RASKIN harus dapat dipertanggungjawabkan kepada masyarakat setempat maupun kepada semua pihak yang berkompeten sesuai dengan peraturan dan ketentuan yang berlaku atau yang telah disepakati.

Kaitannya dengan pengelolaan program Beras Miskin (RASKIN), maka yang dimaksud dengan efektivitas di sini adalah dengan mengukur indikator keberhasilan pelaksanaan program Raskin adalah tepat sasaran penerima manfaat, tepat kualitas, tepat jumlah, tepat harga, tepat waktu dan tepat administrasi.

1. Tepat Sasaran Penerima Manfaat; RASKIN hanya diberikan kepada RTM penerima manfaat Raskin hasil musyawarah desa/kelurahan yang terdaftar dalam DPM-1 dan diberi identitas (Kartu RASKIN atau bentuk lain).

2. Tepat kualitas; beras raskin yang disalurakan harus beras yang berkualitas dan tidak berbau.

3. Tepat Jumlah; Jumlah beras RASKIN yang merupakan hak penerima manfaat adalah sebanyak $10 \mathrm{Kg} / \mathrm{RTM} /$ bulan selama 12 bulan sesuai dengan hasil musyawarah desa. 
4. Tepat Harga; Harga beras RASKIN adalah sebesar 2.500 rupiah per $\mathrm{Kg}$ netto di Titik Distribusi.

5. Tepat Waktu; Waktu pelaksanaan Distribusi beras RASKIN kepada RTM Penerima Manfaat Raskin (PMR) sesuai dengan Rencana Distribusi.

6. Tepat Administrasi; Terpenuhinya persyaratan Administrasi secara benar dan tepat waktu.

Untuk mencapai efektivitas penyaluran Raskin, maka mekanisme pelaksanaannya perlu diatur dengan baik sebagaimana dikemukakan dalam buku Pedoman Umum "Raskin" (Beras Untuk Rumah Tangga Miskin) yang dikeluarkan oleh Kementerian Koordinator Bidang Kesejahteraan Rakyat Republik Indonesia, Tahun 2011.

\section{METODE PENELITIAN}

Metode penelitian yang digunakan dalam penelitian ini adalah metode deskiptif kualitatif untuk menghasilkan temuan atau kebenaran yang disebut kebenaran inter subyektif, yakni kebenaran yang dibangun dari jalinan berbagai faktor yang ber-kerjasama, seperti perilaku pada beberapa individu atau kelompok. Penelitian kualitatif deskriptif merupakan penelitian yang dimaksudkan untuk mengumpulkan informasi mengenai status variabel, gejala, atau keadaan yang ada, yaitu keadaan gejala menurut apa adanya pada saat penelitian dilakukan.

\subsection{Lokasi penelitian}

Penelitian dilakukan di desa Manyarejo, Kecamatan Plupuh, Kabupaten sragen, dengan pertimbangan di desa tersebut pelaksanaan Program Raskin banyak terjadi kendala dilapangan.

\subsection{Sumber Data}

Data primer adalah data yang bersal dari Nara sumber yang terlibat langsung dalam pelaksanaan Raskin di desa Manyarejo, Kecamatan Plupuh, Kabupaten sragen, Informan (responden) yaitu warga penerima Program Raskin (RTS-PM) desa Manyarejo, Kecamatan Plupuh, Kabupaten sragen. Data sekunder adalah data yang berasal dari bahan kepustakaan yang berupa peraturan perundang-undangan, buku-buku, karya ilmiah, koran, majalah, internet serta dokumen-dokumen yang ada hubungannya dengan obyek penelitian

\subsection{Teknik pengumpulan Data}

Teknik pengumpulan data menggunakan teknik Wawancara dan Observasi untuk mendapatkan data Primer, sedangkan data Sekunder 
didapat dari dokumentasi data, arsip, catatan, dan laporan yang ada di desa Manyarejo, Kecamatan Plupuh, Kabupaten Sragen. Wawancara adalah teknik pengumpulan data yang digunakan peneliti untuk mendaspatkan keterangan lisan melalui bercakap-cakap dan berhadapan muka dengan orang yang dapat memberikan keterangan pada si peneliti. Observasi adalah tehnik pengumpulan data melalui pengamatan langsung dari dekat terhadap obyek penelitian.

\section{HASIL DAN PEMBAHASAN}

Efektivitas pengelolaan beras untuk rumah tangga miskin (Raskin) adalah proses pelaksanaan program Raskin dilihat dari aspek efektivitasnya, yaitu ukuran keberhasilan pelaksanaan program Raskin 6T, yang meliputi : tepat sasaran penerima manfaat, tepat kualitas, tepat jumlah, tepat harga, tepat waktu dan tepat administrasi.

\section{Tepat Sasaran Penerima}

Penetapan sasaran atau rumah tangga penerima manfaat program ini berdasarkan pada Basis Data Terpadu yang dikelola oleh TNP2K (Kemenko Kesra, 2013). Berdasarkan pada hasil survey lapangan menunjukkan tingkat ketepatan sasaran di lokasi penelitian sebagai berikut jumlah RTS-PM DPM2 Desa Manyarejo Kecamatan Plupuh Kabupaten Sragen sejumlah 202 penerima sesuai dengan DPM1 yang didata oleh Tim Raskin.

Data tersebut diatas menunjukkan bahwa tingkat efektivitas program ini dilihat dari tingkat ketepatan sasaran mencapai 100\% atau masuk dalam kategori sangat memuaskan. Data tersebut menjelaskan bahwa di salah satu wilayah, yakni Desa Manyarejo jumlah rumah tangga yang menerima bantuan ini rumah tangga yang terdaftar dalam DPM 1. Hal tersebut disebabkan oleh dilaksanakannya semua tahapan-tahapan program raskin sesuai dengan juklak dan juknis pedoman umum raskin. Menurut Walujo (2009), keberhasilan dalam efektivitas ketepatan sasaran program ini dipengaruhi kualitas sumberdaya manusia aparat kelurahan.

\section{Tepat Kualitas}

Kualitas beras yang di distribusikan ke RTS-PM desa Manyarejo berkualitas bagus, berasnya berwarna putih dan beraroma wangi sesuai dengan harapan masyarakat. Data tersebut didapat dari asil observasi dengan masyarakat RTS-PM yang merasa puas dan senang dengan kualitas beras Raskin yang didistribusikan tersebut. 


\section{Tepat Jumlah}

Jumlah yang diterima oleh masing-masing rumah tangga yakni 15 $\mathrm{kg} / \mathrm{KK} /$ bulan (Kemenko Kesra, 2013). Dari hasil survey lapangan menunjukkan bahwa semua sampel menerima jumlah beras sesuai dengan ketetapan yang ada.

\section{Tepat Harga}

Salah satu indikator yang menentukan tingkat efektivitas pelaksanaan program ini adalah tepat harga. Menurut Kemenko Kesra (2013), harga tebus Raskin sebesar Rp 1.600,00/kg. Hasil wawancara dengan seluruh responden menjelaskan bahwa mereka membayar beras $\mathrm{Rp}$ $1.600 / \mathrm{kg}$ dan dibayarkan kepada petugas saat pengambilan beras. Hal tersebut menjelaskan bahwa tingkat ketepatan tebus Raskin mencapai $100 \%$, artinya efektivitas program ini dilihat dari segi ketepatan harga adalah memuaskan. Menurut Hastuti, dkk (2012) ketepatan harga Raskin ditentukan oleh jarak titik distribusi dari penerima manfaat dan fungsi titik distribusi. Berdasarkan hasil survey lapang, titik distribusi dikedua desa ini sangat mudah dijangkau tidak perlu membayar biaya tambahan.

\section{Tepat Waktu}

Masih terjadi hambatan dalam pelaksanaan Raskin di desa Manyarejo, seperti yang dikemukakan oleh pihak pelaksana Raskin dan RTS_PM, akses jalan menuju desa Manyarejo agak buruk sehingga mempengaruhi waktu distribusi Raskin. Dan juga komunikasi dengan ketua RT yang masih belum optimal sehigga menjadikan penyaluran Raskin ke RTS-PM tidak tepat waktu dan tidak sesuai jadwal yang sudah ditentukan. Data diatas menjelaskan bahwa rata-rata tingkat ketepatan waktu distribusi bantuan beras ini belum mencapai $100 \%$, artinya efektivitas dari program ini belum memuaskan.

\section{Tepat Administrasi}

Pendataan RTS-PM merupakan fokus utama dan pertama di desa Manyarejo guna mendukung keberhasilan dan efektivitas penyaluran Raskin. RTS-PM diharuskan memiliki Surat Rumah Tangga Miskin (SRTM), dan Kartu Perlindungan Sosial (KPS), sebagai kelengkapan. Sedangkan data yang dipakai adalah data Pendataan Program Perlindungan Sosial dari BPS Kabupaten Sragen. Hal tersebut menjelaskan bahwa tingkat ketepatan Administrasi Raskin mencapai 100\%, artinya efektivitas program ini dilihat dari segi ketepatan Administrasi adalah memuaskan.

Untuk efektivitas SDM pelaksanan dalam pengelolaan program Raskin, selain penerapan fungsi-fungsi manajemen secara benar dan konsisten, juga 
harus mempertimbangkan beberapa nilai dasar yang dikenal dengan istilah "prinsip-prinsip pengelolaan".

Keberpihakan kepada Rumah Tangga Miskin (RTM), hal ini dilakukan dalam sistem pendataan RTS_PM, sebagai contoh ketika RTS-PM ada yang meninggal maka akan ada pemutakhiran data dengan mengganti RTS-PM yang diambilkan dari keluarga atau saudaranya. Kalau sudah tidak ada maka akan diganti dengan RTS-PM yang lainnya dengan mengisi Formulir Rekapitulasi Pengganti (RPS) selanjutnya akan dikirim ke Kecamatan dan Perum BULOG.

Transparansi, Pemerintah Desa Manyarejo melalui pelaksana distribusi raskin memberikan keterbukaan data terkait pelaksanaan program raskin seperti jadwal, pelaksanaan penyaluran, biaya tebus, jumlah beras, serta informasi mengenai mekanisme pelaksanaan raskin. Mulai dari pendataan RTS-PM sudah diadakan Musyawarah Desa (Musdes) serta dijelaskan tentang prosedur pelaksanaan raskin.

Partisipasi, masyarakat desa Manyarejo sangat partisipatif dilihat dari keterlibatan masyarakat dalam program raskin dari awal proses pendataan, sosialisasi dan pembagian raskin. Selain itu masyarakat juga memberikan pendapat, tanggapan dan keluhan dalam proses pelaksanaan progran raskin.

Pengawasan, pelaksanaan program raskin di awasi oleh pengawas gabungan mulai dari pendataan RTS-PM sampai penyaluran Raskin ke RTS-PM yang terdiri dari pelaksana Desa Manyarejo serta pelaksana Kecamatan Plupuh.

Akuntabilitas, Aktor implementasi kebijakan tidaklah hanya pemerintah. Ada tiga lembaga yang bisa menjadi pelaksana, yaitu pemerintah, kerjasama antara pemerintah-masyarakat/swasta, atau implementasi kebijakan yang diswastakan (privatization atau cintracting out). Dalam Pedoman Umum Rakin telah dijelaskan aktor-aktor yang terlibat dalam melaksanakan program ini. Dalam Pedoman Umum Raskin agar mencapai tujuan yang telah ditentukan dibentuklan Tim Koordinasi di setiap Kota, Kecamatan maupun Kelurahan Hasil interview yang dilakukan oleh peneliti dapat diketahui bahwa tim pelaksana Program Raskin sudah dibentuk sesuai dengan tingkatannya. Tim Kelurahan juga sudah memilih atau menunjuk masyarakat untuk menjadi koordinator di RW nya masingmasing. Pemilihan koordinator RW berdasarkan hasil kesepakatan dari Kelurahan. 


\section{PENUTUP}

\subsection{Kesimpulan}

Pelaksanaan Program Raskin di Desa Manyarejo, Kecamatan Plupuh Kabupaten Sragen berjalan lancar dan sudah sesuai dengan pedoman umum Progran Raskin yang ada. Hal tesebut bisa dilihat dari beberapa aspek penilain tentang efektivitas yang dinilai dari $6 \mathrm{~T}$ yaitu tepat sasaran penerima manfaat, Raskin yang dibagikan telah sesuai dengan RTS-PM yang terdaftar dalam DPM1 dan DPM2 sehingga para RTS-PM menjadi terbantu dalam mengurangi beban pengeluaran sehari-hari; tepat kualitas, kualitas Raskin yang diterimakan kepada RTS-PM mempunyai kualitas yang baik, beras yang putih, harum, tidak berwarna kuning apek dan berkutu; tepat jumlah, Jumlah yang diterima oleh masingmasing RTS-PM yakni $15 \mathrm{~kg} / \mathrm{KK} /$ bulan sesuai dengan program Raskin dari Pemerintah; tepat harga, tiap RTS-PM membayar beras Rp $1.600 / \mathrm{kg}$ dan dibayarkan kepada petugas saat pengambilan beras; tepat waktu karena kondisi infrastruktur jalan menuju desa Manyarejo masih agak jelek menjadikan keterlambatan dalam pendistribusian Raskin, serta komunikasi dengan beberapa RT yang masih belum maksimal; dan tepat administrasi, Pendataan RTS-PM merupakan fokus utama dan pertama di desa Manyarejo guna mendukung keberhasilan dan efektivitas penyaluran Raskin. RTS-PM diharuskan memiliki Surat Rumah Tangga Miskin (SRTM), dan Kartu Perlindungan Sosial (KPS), sebagai kelengkapan.

Faktor kunci keberhasilan Efektivitas pelaksanaan program Raskin di desa Manyarejo, Kecamatan Plupuh, Kabupaten Sragen tidak lepas dari nilai dasar pengelolaan yang dikenal dengan istilah "prinsip-prinsip pengelolaan" yaitu Keberpihakan kepada Rumah Tangga Miskin (RTM), Transparansi, Partisipasi, Pengawasan, dan Akuntabilitas,

\subsection{SARAN}

Hasil-hasil temuan dalam penelitian ini perlu ditindak lanjuti melalui beberapa : 1). Untuk mengoptimalkan efektivitas pengelolaan program Raskin, khususnya dititik distribusi, maka disarankan agar Tim pelaksana dan pemerintah desa memperbaiki sistem pengelolaannya, terutama berkaitan dengan ketetapan kelompok sasaran RTM penerima manfaat program agar dapat terlayani secara keseluruhan sesuai dengan jumlah RTM, ketepatan pendistribusisian beras ke RTM berkaitan dengan komunikasi dengan RT dan akses jalan ke lokasi. 2). Mengingat program Raskin memiliki dampak positif bagi peningkatan kesejahteraan RTM, maka diharapkan agar program ini terus dilaksanakan secara kontinu/berkelanjutan dengan terus-menerus memperbaiki manajemen 
pendistribusiannya sehingga dapat menjangkau seluruh RTM yang ada dititik distribusi (desa).

\section{DAFTAR PUSTAKA}

Arimbi. 1993, Peran Serta Masyarakat dalam Pengelolaan lingkungan. Jakarta: PT.Elexa Raya

Aswardi. 2014, Implementasi Raskin di kecamatan Ternate Riantang Kabupaten Bone. UNHAS, Makasar

Brech E F L. 2002, The principle and practice of management. Jakarta: PT.Rineka Cipta

Campbell, Reece Michell. 1989, Efektivitas. Jakarta: Erlangga

Dwiyanto, Agus. 2006, Penilaian kinerja organisasi publik seminar kinerja organisasi sektor publik, kebijakan dan penerapannya. Yogyakarta: Fisipol UGM

Gibson James L. 2002, Manajemen sumber daya manusia. Jakarta: Erlangga

Hadari, Nawawi. 2001. Manajemen sumber daya manusia Konsep, Teori dan pengembangan dalam konteks organisasi publik. Yogyakarta: Gaddjah Mada University Press

Handayaning, Soewarno. 1994, Efektivitas organisasi. Jakarta: Gramedia Pustaka Utama

Harahap, Sofyan. 2001, Sistem Pengawasan Manajemen. Jakarta: Penerbit Quantum

Isbandi, Rukminto Adi. 2007, Partisipasi Masyarakat. Yogyakarta: Graha Ilmu

Jalaludin, Rakhmat. 2001, Metode Penilitian Deskriptif. Yogyakarta: Pustaka Pelajar

Moleong, J Lexy. 2001, Metodologi penelitian kualitatif. Bandung: PT. Remaja Rosdakarya

Musawa, Mariyam. 2009, Studi Implementasi Program Raskin di Kelurahan Gajah Mungkur, Kecamatan Gajah Mungkur, Kota Semarang. Thesis,UNDIP Semarang

Nazir, Muhammad. 1998, Metode Penelitian. Jakarta: Ghalia Indonesia

Payana Dwi, AAGN, Ari. 2002, Masyarakat Transparansi Indonesia, Supermasi Hukum, Modul. Jakarta

Radwan, S., dan T. Alfthan, 1978, Household Survey For Basic Needs : Some Issues, International Labour Review. Vol.117, No. 2.

Simbolon M, Maringan. 2004, Tujuan dan Jenis-jenis Pengawasan. Bandung: Penerbit Mandar Maju

Sumarsono, Sony. 2003. Ekonomi Manajemen sumber daya manusia dan ketenagakerjaan. Yogyakarta: Graha Ilmu

Steers, M Richard. 1985, Efektivitas Organisasi. Jakarta: Erlangga

Terry, G.R. 2006, Principle of Management. Jakarta: PT. Rineke Cipta

Trisnawati, Ernie dan Kurniawan, Saefulah. 2005, Jenis dan Fungsi Pengawasan. Jakarta: Penerbit Kencana

Wahyuni, Ayu. 2002, Implementasi kebijakan program raskin di desa Toapaya Selatan, Kecamatan Toapaya, Kabupaten Bintan. UMRAJ, Tanjung Pinang

Buku RPJM-Des (Rencana Pembangunan Jangka Menengah) Desa Manyarejo Tahun 2013-2019

Inpres No 5 Tahun 2015 tentang Kebijakan Pengadaan Beras Butir Kelima Pedoman Umum Raskin Tahun 2015 